This is the version of the chapter accepted for publication in Sport and Diplomacy: Games within Games published by Manchester University Press https://www.manchesteruniversitypress.co.uk/9781526131072/

Accepted version downloaded from SOAS Research Online: https://eprints.soas.ac.uk/31196/

\title{
“Barnstorming Frenchmen: The Impact of Paris Université Club’s U.S. Tours and the Individual in Sports Diplomacy"
}

\author{
By Dr. Lindsay Sarah Krasnoff ${ }^{1}$
}

\section{Introduction}

The young men of Paris Université Club (PUC), France's elite basketball team of the mid-1950s, rocked back and forth across the chilly Atlantic waters. It was supposed to be a joyous five-day journey from Le Havre to New York. Instead, most players remained in bed, too seasick to leave their bunks aboard the America. Nobody ate in the dining room; instead sandwiches were placed on cabin floors so that the Frenchmen could roll off, eat, then roll back onto their berths without having to stand up.

Thus began the trip by the first French basketball team to the United States after 1945. In a series of exhibition games, they barnstormed their way through the Midwest and mid-Atlantic. Despite the ominous start, PUC's December 1955-J anuary 1956 tour was a success on many levels. Athletically, it introduced the team to the U.S. style of play and the place basketball—and sports in general-occupied in American culture. The experience also opened the Frenchmen's eyes to what the United States was really like for, with the exception of PUC's American player and voyage organiser Martin Feinberg, it was the first time that any of them set foot on U.S. soil. The team returned in J anuary

\footnotetext{
${ }^{1}$ Portions of this chapter form the basis for elements of the forthcoming manuscript Lindsay Sarah Krasnoff, 'French Cagers' (forthcoming).
} 
1962, another seminal experience that demonstrated the power of basketball, imparted U.S. culture, and portrayed the verities of racial attitudes and the J im Crow segregation of whites and blacks in pre-Civil Rights United States.

The two trips broke ground for the amateur club. Neither was sponsored by the U.S. Government, although the they occurred as the U.S. Department of State began to organise goodwill tours for its athletes and coaches. Nor were they part of any French government plan to exhibit athletic prowess abroad or improve performances-such official use of sport to cultivate soft power via victories stared after the 1960 Olympics, the 'zero hour' of the country's sports crisis, a failure to win many accolades or titles that lasted until the mid-1970s. Instead, these jaunts were the brainchild of a tall young man from Cleveland, Ohio, who wanted his teammates to see his homeland and learn about its culture, society, and basketball.

PUC's experience of the United States influenced the Frenchmen's views and understanding of the country through the opportunity to travel and interact with everyday American citizens. Effectively, the trips presaged one of the major ideas that underwrites official U.S. Government sports diplomacy today: that through the universal power of sport, citizens from different countries can learn more about the United States and people in ways that policy speeches or press accounts cannot convey. Interactions with private individuals can be potent tools, a window into a society, an up close personal exchange of ideas that can cut through officially disseminated information.

The PUC tours were thus sterling examples of the merits of sports exchanges as elements of diplomacy, even though they were not government-sponsored or even public-private partnerships. Rather, Feinberg's organisation proved the power of the 
individual, what Giles Scott-Smith calls the 'new diplomacy,' in which private citizens can informally play diplomatic roles. ${ }^{2}$ Today one would refer to this as people-to-people diplomacy, but back then the concept had yet to be coined; it was merely a goodwill gesture instigated by one individual. That the PUCists, as PUC players and alumni were called, later drew upon their U.S. experiences to help remedy French basketball during the sports crisis testifies to the importance of sport as a diplomatic tool, even the unofficial, grass-roots level variety.

\section{The New Power of Sport}

France had to recalibrate itself for the realities of the post- 1945 world. Its Great Power status was superseded by new superpowers, the United States and the Soviet Union, and the hexagone, as the country is sometimes called in reference to its shape, adjusted-but not easily. Caught between Moscow and Washington, Paris sought to reestablish itself via the influence it carried through its overseas holdings. Unfortunately for the Élysée Palace, Indochina's fight for independence (1946-1954) followed by the start of Algeria's struggle to throw off the yoke of empire (1956-1962) toppled the Fourth Republic and brought General Charles de Gaulle back to power as president of the Fifth Republic in 1958. Within a few short years, its holdings in Africa declared full sovereignty from the republic (1960), while other overseas possessions became direct administrative departments, such as Martinique and Guadeloupe (1964).

It was not just the geographical makeup of France that fluctuated during this time. The demographic composition of the mainland also changed as workers from former imperial holdings in North and Sub-Saharan Africa, as well as the Antilles,

2. Gilles Scott-Smith, 'Introduction: Private Diplomacy, Making the Citizen Visible,' New Global Studies, April 2014, 2-3. 
arrived to fuel the thirty 'glorious years' of postwar economic recovery. They staffed factories, took menial jobs that metropolitan workers did not want, and put down roots. As they did, the notion of who was French started to change.

The concept of French citizenship is one firmly entrenched in jus soli-citizenship of the soil-one that dates back to the French Revolution of the late eighteenth century. This means that anyone can become French if they are born on its territory, or become naturalised citizens through an examination and assimilation into the national fabric via speaking the language, adhering to secularisation in the public sphere (since 1905), respecting republican ideals set forth in the Declaration of the Rights of Man and Citizen, service to the state, adapting French-style dress, etc. Like the United States on the other side of the Atlantic, France was thus an immigrant destination for centuries, a place where one could theoretically advance based on merit and ability if one inserted oneself fully into public life. By the postwar period, France assimilated waves of J ews and others from Eastern and Central Europe, particularly Poland, Spain, Italy, and by the late 1950s and 1960s, Portugal, as citizens. While some subjects of the French Empire in Africa attained citizenship prior to the Second World War, the majority only did so after the passage of the 1946 Fourth Republic constitution.

Sports was one of the easiest ways for generations of immigrants, citizens, and subjects from all backgrounds to assimilate into French life and solidify their 'French' identity. Players of colour represented France in international competition, such as Senegal-born Raoul Diagne and Moroccan-born Labri Ben Barek in football in the 1930s, as did players of Polish, Spanish, and Italian descent, such as Raymond Kopa in the 1950s. Sport thus helped reinforce national identity, regardless of skin colour or religious background. This trend continued in the postwar period, as the sons, 
daughters, grandsons, and granddaughters of immigrants represented France at the highest levels of athletic competition.

Such rapid changes in the composition of 'who was French' initially paled in the 1950s and 1960s in comparison to the larger anxiety over 'what was French?' This predicament was inflamed by the large number of children born in the 1940s and 1950s, an unprecedented swelling of the demographic bulge, who started to come of age and challenge parental authority. This generation, known as the baby-boomers, started to strain the schools and challenged long-held social norms. ${ }^{3}$ The baby-boomers embraced U.S. cultural imports to the horror of many elders and opinion makers. From drinking Coca-Cola to listening to Elvis to watching 'spaghetti western' television shows, young French of the 1950s turned to the United States as the cultural capital of cool. ${ }^{4}$ Youth's embrace of all things American fed into the start of a cyclical period of anti-Americanism. Such proclivities peppered French discourse dating back to the late eighteenth century. What began as a rejection of U.S. culture morphed, as Philippe Roger argues, into a conduit of dissatisfaction with the politics and policy of France's sister republic. ${ }^{5}$ By the twentieth century, the hexagone's anti-Americanism coincided with periods of waning hegemony or anxiety about the country's soft power influence. 6

3. For more on the baby-boomers, their importance in portraying a rejuvenated France, and the 'youth crisis' that started in the late 1950s, see Lindsay Sarah Krasnoff, The Making of Les Bleus: Sport in France, 1958-2010, (LanhamMD: Lexington Books, 2013), 25-33; Kristin Ross, Fast Cars, Clean Bodies: Decolonizaiton and the Reordering of French Culture, (Cambridge MA: MIT Press, 1995); Richard Ivan Jobs, Riding the New Wave: Youth and the Rejuvenation of France After the Second World War, (Stanford: Stanford University Press, 2007).

4. See Krasnoff, ibid; also Richard Kuisel, Seducing the French: The Dilemma of Americanization, (Berkeley University of California Press, 1993) and Victoria de Grazia, Irresistible Empire: America's Advance Through Twentieth Century Europe, (Cambridge MA: Harvard University Press, 2006) for more on American cultural trends and impacts in mid-century France.

5. See Philippe Roger, The American Enemy: A Story of French Anti-Americanism (Chicago: University of Chicago Press, 2005).

6. Other works that chronicle and examine the history of French anti-Americanism include Richard F. Kuisel, The French Way: How France Embraced and Rejected American Values and Power (Princeton, N.J.: Princeton University Press, 2012) and Seducing the French: The Dilemma of Americanization (Berkeley: University of 
Parents and grandparents need not have worried excessively; once the baby-boomers matured in the 1960s, anti-Americanism began to emerge more profusely as the youth started to protest escalating U.S. intervention in Vietnam and overwhelmingly took their cultural cues from Britain. ${ }^{7}$

De Gaulle thus confronted a multitude of issues when he resumed the reins. Counteracting global images of an old, defeated France invaded by sugary sodas and hip-swivelling rock ' $n$ rollers was ever more important under his presidency. Revival was the message the Élyssée wished to impart to the world, a rejuvenated France buoyed by its newfound youth and vigour, free of empire, and a leader for those seeking an alternative path to Washington and Moscow's Cold War clout. J ust as French power was conveyed through its world-renown leadership in the arts, literature, gastronomy, and cinema, sports was another domain that could be deployed to the republic's advantage. Thanks to a new era of communications, namely the grouth of television and the first satellite-diffused broadcasts into private homes, images of athletes collecting accolades held new potency. Thus, in many ways, the power of media amplified that of sport and provided new ways for athletes to embody the nation.

The French government was not unique in turning to sport as a soft power tool. Major international competitions were quickly politicised in the early twentieth century, an action that nulled their original intention to promote peace and harmony. Subsequently, countries hijacked the high profile stage such tournaments provided to assert primacy, such as Nazi Germany in 1936. The Soviet Union's 1952 entry into the

California Press, 1993), Seth D. Armus, French anti-Americanism (1930-1948): Critical Moments in a Complex History (Lanham, MD: Lexington Books, 2007), and David Strauss, Menace in the West: The Rise of French antiAmericanism in Modern Times, (Westport, Conn.: Greenwood Press, 1978).

7. See Krasnoff, The Making of Les Blues. 
Olympic movement upped the Cold War ante and forced its nemesis in North America to integrate, albeit slowly, sport into its diplomatic toolbox.

The U.S. Government began limited cultural exchange programs in the early 1950s. ${ }^{8}$ According to Roy Clumpner, the U.S. Department of State was keyed into the importance of sport before mid-decade, prodded by the Soviet sport 'offensive. ${ }^{9}$ This perceived onslaught included deployment of several USSR teams abroad, a powerful move that swayed Foggy Bottom and resulted in President Dwight Eisenhower's authorisation of limited funds to send U.S. teams abroad. ${ }^{10}$ Yet, convincing the U.S. Congress of the need to sponsor international athletic endeavours remained a tricky task. As Rachel Vaughn points out in this volume, the years leading up to the 1960 Winter Games, held at Squaw Valley, were pivotal in swaying the legislative branch to open the coffers for sports diplomacy. ${ }^{11}$

Sport was used not only to counterbalance the East versus West Cold War dynamic, but also by other states to cultivate soft power. Amanda Sherman's chapter in this book examines how the People's Republic of China used sports exchanges and visits in the 1950s and 1960s to build friendly ties to countries within the Eastern Bloc, as well as newly decolonized Africa. ${ }^{12}$ Such missions, she argues, served to shore up the PRC's legitimacy in the eyes of the international community at a time when it vied with the

8. The U.S. Department of State, through provisions of the Fulbright Act and the Smith-Mundt Act, which provided funding for cultural diplomacy and information programs, began to send a few coaches and players abroad.

9. Roy A. Clumpner, 'American Federal Government Involvement in Sport, 1888-1973,' PhD Thesis, (Edmonton, Alberta, Spring 1976), 316.

10. President Dwight Eisenhower's 1954 Emergency Fund for International Affairs provided substantive financial support for cultural diplomacy programing but sports exchanges did not get more substantively underway until later in the decade. For more details on the evolution of U.S. Government sports exchanges and diplomacy initiatives, see Clumpner, Chapter XIII 'Federal Involvement to Promote American Interests or Foreign Policy Objectives, 19501973.'

11. Rachel Vaughan, 'Two Chinas Diplomacy and the 1960 Squaw Valley Winter Olympics,' paper presentation at SOAS, University of London, 'Message, Mode and Metpahor' Sport \& Diplomacy conference, July 2015, 15. 12. Amanda Shuman, "Friendship is Solidarity: The Chinese Ping-Pong Team Visits Africa in 1962," Sport and Diplomacy: Games Within Games, (Manchester: Manchester University Press, 2018). 
Republic of China (Taiwan) to be viewed as the internationally-recognized government of China.

There was thus a conscious shift by many governments to incorporate sports exchanges, visits, and competitions to cultivate their power via global public opinion. The general concept of 'nation branding,' or creating an identity via projection of a country's image to foreign publics, was not new. Especially for France, which J an Melissen argues did so as early as the ancien régime under Louis XIV. ${ }^{13}$ But the postwar international order gave impetus for countries to deploy new tactics in their quest to influence societies around the world. By this era, Melissen notes, such image cultivation extended to groups not officially affiliated with a government, thus giving more power to non-state actors.

Some of the key organizations that recognised the potency of sport postwar included the international athletic governing federations. The postwar era was one in which many of the world's largest, most popular sports reorganised. That they did so outside of the new bipolar particulars of the geopolitical scene gave them degrees of autonomy from the larger diplomatic transformations that shaped the international arena, as Grégory Quin, Nicola Sbetti, and Philippe Vonnard note in the case of the Fédération International de Football Association (FIFA), which they argue became a new environment for diplomacy. ${ }^{14}$ Thus, the definition of who was an arbiter of diplomacy began to shift as the new era of public diplomacy enabled athletes to serve as more potent diplomatic ambassadors.

13. Jan Melissen, ‘The New Public Diplomacy: Between Theory and Practice', in Jan Melissen (ed.), The New Public Diplomacy: Soft Power in International Relations, (Palgrave Macmillan, 2005), 3-6.

14. Grégory Quin, Nicola Sbetti, and Philippe Vonnard, 'FIFA's reconstruction after the Second World War: a matter of diplomacy?’ draft paper, SOAS, University of London, 'Message, Mode and Metpahor’ Sport \& Diplomacy conference, July 2015, 3. 
Grasping at sports for cultural influence was not a far stretch of the imagination for France. One of its citizens, Baron Pierre de Coubertin, birthed the modern Olympics in 1896. Through the mid-twentieth century, Frenchmen led the development of international athletic governing bodies. The hexagone was a founding member of FIFA in 1906 and two of its citizens played outsized roles in moulding the world's largest, most powerful sports entity. ${ }^{15}$ France was a founding member of the Fédération International Medico-Sportive (FIMS) in 1928 and joined the nascent Fédération International de Basketball Amateur (FIBA), the second-largest federation by midcentury, a year after that body's 1932 establishment.

French sports leadership also played out on the field. The nation's Olympians garnered enough medals at the first ten Olympiads to place in the top five in the overall medal counts seven times. The men's basketball team, Les Tricolores, today known as Les Bleus, won the bronze medal at the 1937 European Championship, while the women's team placed fourth at the 1938 tournament. ${ }^{16}$ Postwar, France continued to lead. At the 1948 London Games, France placed third in the overall medal count with its

15. French nobleman Pierre de Coubertin pushed for the first modern Olympics, held in Athens in 1896. The event showcased the ideals of amateurism and promoted international peace. Frenchman Jules Rimet had an outsized role within FIFA, starting with his organization of the first World Cup in 1930 during his long tenure as FIFA president from 1921 to 1954. Rimet and fellow countryman Henri Delaunay were also driving forces in creation of the European Championship of football, a concept both advocated for decades prior to its 1960 inception. See UEFA, 'UEFA European Football Championship Origins,' http://www.uefa.com/uefaeuro/history/background/index.html accessed 26 April 2017.

16. Certain sports in France were viewed as more suitable for men or for women. For example, football was considered too violent and physical for women to play until the late twentieth and early twenty-first centuries. Basketball, on the other hand, was perceived to be well-suited for the female physique as early as the 1890s. Thus, women's basketball has a long, strong history and the national team excelled at international competitions. For further background, see Mary Lynn Stewart, For Health and Beauty: Physical Culture for Frenchwomen, 1880s1930s, (Harvard University Press, 2000), and for the wider European context in the late nineteenth and early twentieth centuries Davia Majauskieine, Vilma Cingiene, Mindaugas Bobikas, 'Traits caractéristiques de l’évolution du basket-ball féminin en Lituanie (1920-1940),' in Fabien Archambault, Loic Artiaga et Gérard Bosc, Le Continent basket: L'Europe et le basket-ball au XXe siècle, (Bruxelles: PIE Peter Lang, 2015). 
underfunded but relatively large contingent, a fait accompli facilitated by Les

Tricolores.

Basketball, despite its U.S. roots, was a point of pride for the French and enjoyed a long history dating to the game's 1893 European début in a Paris gymnasium at 14, rue de Trévise. ${ }^{17}$ Despite its early introduction to France, the round ball's association with the Protestant-affiliated Young Men's Christian Association (YMCA), whose instructors taught the sport, hindered its initial popularity during a time of fierce debate over the secular nature of republican public life. Basketball gained traction by the presence of YMCA foyers and U.S. doughboys during the Great War and spread during the Interwar years through the French Army and Catholic Church, which viewed it as a tool to revitalise a youth devastated by the conflict. ${ }^{18}$ Yet, this era was one in which the game's ties with the United States were severed as the hexagone developed its own coaches, stars, and styles of play. The national teams gained acclaim in the 1930s and helped lead the Europeanisation of the sport. ${ }^{19}$ It was the post- 1945 years, however, that ushered in the first 'golden era' of French hoops, a sport that many still associated with the Army, the Church, and the schools. ${ }^{20}$

17. The rue de Trévise facility is today the oldest original basketball court in the world, constructed out of wood imported from North America in 1893. French Basketball Federation, 'Visitez la plus ancienne salle de basket,' French Basketball Federation website, http://www.ffbb.com/visitez-la-plus-ancienne-salle-de-basket accessed 26 April 2016.

18. For more on the sport's early phases in France, including its popularization, see Gérard Bosc in Fabien Archambault, Loic Artaga, et Gérard Bosc, Double Jeu. Histoire du basket-ball entre France et Amérique, (Paris: Vuibert, 2007).

19. As Sabine Chavinier-Réla argues, French rules were adopted in many parts of Europe during the Interwar period until the later 1930s when more American rules were instituted. Sabine Chavinier-Réla, "Les règles du basket français dans l'entre-deux-guerres, entre dimension nationale et continentale," in Fabien Archambault, Loic Artiaga et Gérard Bosc (dir.), Le Continent basket: L'Europe et le basket-ball au XXe siècle, (Bruxelles: PIE Peter Lang, 2015), 30.

20. Les Bleus won the silver medal at the 1947 European Basketball Championship. 
Les Tricolores' silver medal finish at the 1948 Olympics, a David versus Goliath fight against the United States, was instructive. ${ }^{21}$ While the French played against U.S. GIs in the last years of the war-the first basketball game held on liberated Parisian soil occurred in Fall 1944 - and picked up some American forms of play, the London Games began to change the French style. The national sports daily, L'Équipe, reported at the Games that the French lacked precision against their competitors, though they learned U.S. tactics, a key takeaway. ${ }^{22}$

In this sense, the diffusion of basketball skills postwar was similar to what occurred within the realm of football. British football coaches during the late nineteenth and early twentieth century were viewed as leaders in the field, linked not only to their role as originators of the game, but also, as Matthew Taylor points out, reflective of the United Kingdom's role as a global leader. As the British spread the game across Europe through its workers and coaches, Europeans assimilated and bettered UK tactics, such as the defeat of England by Hungary's 'Magical Magyars,' at Wembley Stadium in November 1953. This is a phenomenon that Taylor calls a 'cross-cultural transfer of knowledge,' one in which reworked national games sometimes outflanked that of the original diffusers. ${ }^{23} \mathrm{~A}$ similar transaction occurred with American-style basketball after 1945, a period of unprecedented U.S. military, diplomatic, and cultural power on the international stage.

French hoops thus benefitted from the transfusion of U.S. skills. Les Tricolores won bronze medals at the European Championship (1949, 1953, 1959), fourth place at

21. The 1948 London Games were the second time that basketball was included in the Olympics, the first was Berlin 1936.

22. 'L’Attaque des Tricolores enervée a manqué de raisonnement,' L’Équipe, August 14, 1948, 4.

23. Matthew Taylor, 'Football's Engineers? British Football Coaches, Migration and Intercultural Transfer, c. 1910-

c. 1950s,' Sport in History, Vol. 30, No. 1, March 2010, 156. 
FIBA’s 1954 World Basketball Championship, and fourth place at the 1956 Olympic Games. Many members of Les Tricolores played for PUC, an amateur team. The club, which called Stade Charléty at the southernmost point of Paris' 13ème arrondisement home, won the French championship twice $(1947,1963)$, often played in the league's finals, and won four French Cup trophies (1954, 1955, 1962, 1963). The PUCists were aided first by Martin Feinberg starting in 1955, then 'Gentleman' Henry Fields, an African American recruited to the team by Feinberg in 1962. As PUC teammate Michel Rat recalled decades later, Feinberg played an important role as a teacher who imparted U.S.-style tactics and thus help the club improve. ${ }^{24}$ Fields played a similar role, introducing the defensive style and techniques of U.S. basketball legend Bill Russell, one of the game's modernising tacticians, to France, an element that helped PUC overcome arch-rival Bagnolet to win the 1963 title.

By the mid-1950s, French confidence in their basketball ability was justifiably high. In a report issued by the Institute National de Sport (INS) following the 1956 Olympic Games, officials argued why all resources possible should be given to the sport, even though it was not as popular as football or rugby. The study pointed out that, 'our basketball players are among the best in the world.'25 The logical conclusion was that investment in the round ball would be a good bet to produce more medals, thus shoring up the image of the country as an athletic, youthful, wining one to counter the setbacks suffered by the defeat at Dien Bien Phu (1954), the Suez Canal crisis (1956), and the outbreak of the Algerian War (1956).

24. Michel Rat, interview with the author, 29 June 2015.

25. 'Notes soumises à Monsieur le Dirécteur Général de la Jeunesse et des Sports à propos de la preparation aux JO 1960,' Institut National du Sport, undated, Center of Contemporary Archives (CAC) 19780586, Article 100 JO Rome. 
Intriguingly, the INS report included further rationale behind French hoops prowess. 'Our favourable [Olympic] sports are fencing and basketball,' it stated, reasoning that these were the most intelligent individual and team sports, thus wellsuited to the national psyche. ${ }^{26}$ Players past and present relay that succeeding at the sport's highest levels requires a lot of thought and mental calculation, that it is indeed one of the more cerebral sports. ${ }^{27}$ Yet, at the time the statement may also have sought to couch basketball as a 'French' endeavour. Despite cyclical anti-American sentiment, France previously embraced American cultural constructs, such as jazz, and reworked it into something distinct in its own right. The same could be said of basketball in the first part of the twentieth century.

The 1950s and 1960s, however, were different as American players entered French leagues and introduced U.S.-style techniques and tactics on the hardcourt. Adaption of transatlantic hoops finesse started to be blended into the playbook. This coincided with a similar cultural transmission that occurred within the sphere of music. As J onathyne Briggs argues, in the 1950s and 1960s, the French took American rock ' $n$ roll and turned it into their own genre, illustrated most vividly by J ohnny Hallyday and the Yé-Yés. ${ }^{28}$ For most in the hexagone, basketball was already conceived of as 'French.' Yet, the increased 'Americanisation' of basketball allowed for the same creation of

26. 'Notes soumises à Monsieur le Dirécteur Général de la Jeunesse et des Sports à propos de la preparation aux JO 1960,' Institut National du Sport, undated, Center of Contemporary Archives (CAC) 19780586, Article 100 JO Rome.

27. Michel Rat and Jean-Marie Jouaret, interviews with the author, June 29, (2015); Jacques Cachemire, interview with the author, July 8, (2015); Nicolas Batum, interview with the author, February 4, (2015); Kévin Séraphin, interviews with the author February 23 (2015) and March 11 (2015); Evan Fournier, interview with the author, May 10, (2016).

28. Jonathyne Briggs, Sounds French: Globalization, Cultural Communication \& Pop Music, 1958-1980, (Oxford University Press, 2015), 5. 
multiple spaces of culture that Briggs argues music provided, which 'permitted new possibilities of social interaction. ${ }^{29}$

New spaces for social interaction were indeed found within the realm of basketball. PUC coach Emile Frézot, himself a former Tricolore, was ecstatic to recruit Feinberg during the fall of $1955 .{ }^{30}$ Feinberg was a novelty, even though another American played for PUC a season earlier. It was not just his style of play that made Feinberg so mythical, but the way he taught his new teammates American techniques, as well as his camaraderie. Feinberg quickly became an invaluable asset.

\section{Paris Université Club's First U.S. Tour}

Feinberg organised one of the earliest postwar sports exchanges between France and the United States, albeit an unofficial one. He grew up in Depression-era Cleveland playing basketball, and represented the University of Michigan Wolverines on court while training there with the Navy Air Corps in 1944. Feinberg arrived in Europe in J anuary 1954 after service in the Korean War, toured the countryside, then enrolled at university in Paris to study international relations on his GI Bill benefits (tuition and a \$75 per month stipend).

'T did not go to France to play basketball,' Feinberg maintained decades later. ${ }^{31}$ But two sisters (twins) convinced him to try out for PUC that year. French players were typically not tall—or as tall as Feinberg. The men's coach was thrilled to have a six-footthree American,' he recalled. The 26-year old Ohioan was considerably older than most other players on the team, and he had more on-court experience.

29. Briggs, 4.

30. Martin Feinberg, interview with the author, December 7, (2014).

31. All Feinberg quotes: Martin Feinberg, interview with the author, 7 December 2014, 13 December 2014, and via email to the author, 2 December 2014. 
The American found that the French treated basketball differently. I didn't see real concern about basketball being as major of a sport,' as in the United States, he recalled. It remained a niche endeavour in a country that favoured British sports. Even Roger Antoine, Feinberg's teammate and long-serving captain of Les Tricolores, loved football first and foremost. ${ }^{32}$ Moreover, basketball was a sport of the provinces and midsized urban areas, domains of the bourgeoisie. It was far removed from the boisterousness of working class (football) or upper class (rugby) sports and was one of the few disciplines incorporated into the physical education program in the country's collèges and lycées. ${ }^{33}$ Basketball was thus associated with the middle classes or schools, but also embraced by some of the elite. Future prime minister Lionel J ospin played during his university and military service years and continued to be a regular in local leagues into his 60 s. ${ }^{34}$

The sport's infrastructure confirmed that at times it was an afterthought. The stadiums were horrible,' Feinberg said, most of which were constructed before the war. 'Invariably, we played in places with slippery floors.' There was 'absolutely no comparison' between his experience playing for the Wolverines and what he encountered in France. That's one of the reasons why I wanted to bring the PUC to see this [sic] wondrous of stadiums to play basketball in,' he explained of the team's first U.S. trip. Another consideration was to introduce his teammates to his homeland so that

32. Pierre Tessier, 'Roger Antoine successeur désigné de André Buffière au capitnnat de l'équipe de France,' L'Équipe, September 20, 1955, 5.

33. While the French school system did not incorporate school athletics in the way that American and British schools do, there was a regular PhysEd period.

34. Today, Jospin does not stray too far from the court. In February 2016 he was a guest on one of France's Sunday night basketball programs. Information about Jospin's basketball career extracted from interviews with Feinberg and Rat and 'Basket: Lionel Jospin sur BeIn Sports Pour Comenter sur le basket,' Le Dauphine, 27 February 2016; http://www.ledauphine.com/france-monde/2016/02/27/basket-lionel-jospin-sur-bein-sports-pour-commenter-la-nba accessed 26 April 2016. 
they could see for themselves what the United States was actually like-and how it differed from the version portrayed to the French public by its media and government.

Working with Dan Fearis, general secretary of the American Athletic Union (AAU), then responsible for organising U.S. amateur basketball, Feinberg pieced together a short tour through the Midwest. ${ }^{35}$ The French Government and the University of Paris pledged money to underwrite the trip, and part of the proceeds from ticket sales would defray costs. The players also contributed $\$ 70$ each to participate. ${ }^{36}$ But the plan was more than just to play basketball; the young Frenchmen also wanted to learn and see everything they could about the United States. As L'Équipe noted in their special coverage of the team's tour to U.S. shores, 'the PUCistes, desirous to enrich their cultural plan, demanded that they be accorded visits to the grand American hospitals.' ${ }^{37}$

The front page of L'Équipe's December 21 edition featured a photograph of the team departing aboard the America for New York. ${ }^{38}$ It was thanks to a small miracle that two teammates, Antoine and J acques Owen, made the trip, their visas coming through at the very last minute. 39 Thus, that chilly December morning, Feinberg, seven of his teammates, and Frézot sailed to New York. Quipped LÉquipe, Martin Feinberg was particularly over-playful! The prospect of a return to his homeland exhilarated the American to such a degree that we were unable to recognise this shouting friend as the great lethargic boy who we knew!'40

35. Pierre Tessier, 'Le PUC s’embarquera le 21 décembre pour les États-Unis...,’ L’Équipe, 6 December 1955, 8.

36. 'Events and Discoveries: French Fried,' Sports Illustrated, 16 January 1956.

37. Tessier, 1955.

38. 'Les basketteurs du PUC embarquent les 'Kiwis’ Débarquent,' L'Équipe, 21 December 1955, 1.

39. 'Les basketteurs du PUC embarquent les 'Kiwis' Débarquent,' L'Équipe, 21 December 1955, 1.

40. Gérard Edelsltein, 'Le PUC est parti pour les États-Unis,' L’Équipe, 21 December 1955, 5. 
Excitement permeated the air. Frézot noted that a pilgrimage to the basketball mecca of America was one not only of athletic significance, but also one of cultural importance. This initiative should have been taken a while ago,' he said, so that coaches responsible for the future of the French game could go, observe, and bring back the truths that American basketball has become!'41 Once on board, however, enthusiasm gave way to sea sickness for most of the rough Atlantic passage. The team arrived in New York, then boarded a flight to Chicago on December 28 even while some still suffered from mal de mer. ${ }^{42}$

It was the first time that a French basketball team played on U.S. soil after 1945Les Bleus did not do so until a 1965 friendly match in New York against Poland. Moreover, aside from Feinberg, it was the first time that any of the PUCists visited the United States. They survived on a tight per diem of $\$ 6$ and camped out at a YMCA to save money. ${ }^{43}$ Such frugalness did not dampen the group's excitement. They wished to compete against U.S. teams and see how they fared. Yet, as Feinberg explained to a reporter, 'mostly I'm very much interested in them liking America. That, for me, is the idea.' 44

All were eager to learn and soak up the myths of 'America.' Feinberg recalled a night spent with his Chicago friends and several teammates at the exclusive Pump Room restaurant. The Frenchmen took in the glamorous nightlife. Teammate J acques Huguet, the group's comic and a medical student, entertained the entire room with an

41. Gérard Edelsltein, ‘Le PUC est parti pour les États-Unis,’ L’Équipe, 21 December 1955, 5.

42. Robert Chromie, 'Paris Athletes Say Oui Oui on Chicago Visit,' Chicago Tribune, 29 December 1959, 25.

43. Sports Illustrated, 'Events and Discoveries: French Fried' 16 January 1956, www.si.com/vault/1956/01/16/604289/events--discoveries accessed 1 August 2017. 44. Chromie. 
impromptu monologue. ${ }^{45}$ Another, Roger Zagury, a French J ew from Casablanca, was impressed by it all: the lights, the construction, the newness. It gives the impression that the country isn't finished yet,' he told a reporter, 'not like Europe.'46

PUC's road record was mixed. The team's first stop was Wheaton, Illinois, where they lost their first game (29 December, 68-43). They then won two matches, one against Lake Forrest College (2 J anuary 1956, 69-64) and the other versus North Central of Iowa (3 J anuary, 67-58). U.S. reporters critiqued their style of play. Sports Illustrated remarked that the Frenchmen, 'played a game that looked absurdly old-fashioned,' and 'concentrated on ball control, an occasional well-executed fast break, and set plays off the double-pivot offence.' 47 After a 74-43 loss to Marquette University, the Milwaukee Sentinel reported that, 'what the Parisians lacked in cage know-how and finesse they tried to make up with ésprit de corps.' 48 Another loss to DePaul University in Chicago (5 J an, 71-45) and then to University of Baltimore in Baltimore (9 January, 76-68) served up further fodder for critique. As Sun reporter Walter Herman noted,

Baltimore, like most United States college teams, utilizes [sic] the shootand-run offense [sic] and zone defense [sic]. Paris, on the other hand, has a tight and very effective man-for-man defense [sic] and, in spite of a height deficiency, grabbed more than its share of rebounds.' 49 By the end of their tour, the team was exhausted and nearly broke. Feinberg remained behind in a Cleveland hospital with a torn Achilles tendon, thus the Frenchmen were left

45. Feinberg, Interview with the author, 7 December 2014.

46. Chromie.

47. Sports Illustrated, 'Events and Discoveries: French Fried’ 16 January 1956, www.si.com/vault/1956/01/16/604289/events--discoveries accessed 1 August 2017.

48. Rel Bochat, 'Marquette Routs Paris 'Five,' 74-43,' The Milwaukee Sentinel, 5 January 1956, 11.

49. Walter F. Herman, 'Baltimore U. Holds Off Late Rally To Top Paris, 76-68,' Baltimore Sun, 10 January 1956. 
without an interpreter. 50 They showed up to their J anuary 9 game in Baltimore soaking wet after getting caught in the rain and hungry as they only ate a light breakfast that day. ${ }^{51}$ Living on such a tight budget showed its mark.

While the Department of State began to organise athletic exchanges by this point, the U.S. Government did not officially sponsor PUC's 1956 or 1962 tours. ${ }^{2}$ The Department, however, was reportedly interested in the initiative and dispatched Voice of America staff to broadcast the J anuary 1956 Baltimore game to France. 53 Feinberg and his teammates returned home, alongside the fond memories and impressions of what they saw.

\section{The Return}

Feinberg's role at PUC changed by the early 1960s, after finishing his studies, from player to coach. He continued to serve as a mentor on the court and made friends with new teammates, such as Rat, a Parisian native who joined PUC in 1959. In 1962, Feinberg recruited 'Gentleman Fields,' as the six-foot-five New York native was known, from the U.S. military airbase in Orléans. ${ }^{54}$ Upon his release from service that year, Fields joined PUC on the court. 55 Both Rat and Fields were part of the December 1962 tour Feinberg organised for the team.

The goal that winter, just as for the previous trip, was not necessarily for PUC to play games. Instead, it was about taking it all in—at heart, the ultimate goal of any

\footnotetext{
50. Feinberg.

51. Feinberg.

52. Feinberg.

53. Patrick Skene Catling, '’Foul' Situation Fails to Slow French Team of 'Only Seven,' Baltimore Sun, 10 January 1956, 36.

54. 'Henry Fields, le basket de New York à Auterive,' La Croix, 18 September 2009, http://www.la-

croix.com/Actualite/Sport/Henry-Fields-le-basket-de-New-York-a-Auterive-_NG_2009-09-18-539439 accessed 26 May 2017.

55. Henry Fields, interview with the author 30 June 2015.
} 
sports exchange. 'T loved the United States,' Feinberg said, 'and wanted them to learn about basketball and Americans.' That they did, as the team was exposed to the complex race issues that shaped U.S. society.

PUC set out for the United States that December by airplane. They won their first game against Gallaudet University in the Baltimore-Washington corridor (18 December, 42-39). They then lost to Oglethorpe (20 December, 87-37) and Brownston, an AAU team, (2? December, 68-66). The record was not ideal, but the PUCists certainly learned a lot about the United States.

Along the way, the barnstorming Frenchmen were baptised into the bliss of American-style basketball shoes. At the time, the French called any type of sneaker a 'tennis shoe.' According to Feinberg, the ones available in France were heavy and not ideal for playing basketball. There was nothing on the market akin to the U.S.-produced Converse basketball sneakers that Feinberg wore. PUC was once again on a shoestring budget, but Feinberg devised a tactic: he arranged a radio interview for the team, after which each player received a pair of Converse sneakers. 56 They were very generous, the Americans,' Feinberg said, 'wherever we asked for the tennis shoes [basketball sneakers], we got them.' Rat related how important such gestures were for the Frenchmen. 'We had French sneakers, like the Busnel,' he said of the model named after Les Tricolores' coach during its golden heyday, Robert Busnel. ${ }^{57}$ Yet, 'everyone was crazy for Converses,' raved Rat, 'because they were American products.'58

56. Feinberg, 7 December 2014.

57. Robert Busnel also served as coach of the national women's team, 1948-1960. He was named president of the French Federation of Basketball (FFBB), in 1966, a position he held until his 1984 election as president of FIBA. In 1990, he stepped down from the presidency after steering the sport through a phenomenal period of international growth, driven by the rise of the NBA.

58. All Rat quotes: Michel Rat, interviews with the author, 22 October 2014, 29 June 2015, and 20 October 2015. 
The Frenchmen were also introduced to J im Crow segregation in which blacks had supposedly 'separate but equal' public spaces from whites, whether it be drinking fountains, restaurants, schools, or where to sit on the bus. Unlike the 1956 trip through the Midwest, in 1962 the team played teams in the South. Following the Gallaudet game, the team boarded a bus bound for Atlanta, where they would play Oglethorpe. En route, their clothes were lost, according to Fields, so the team played the game in what they wore on the trip. 59 While in the Atlanta area, the bus stopped to refuel and the PUCists took advantage of the break to grab refreshment at the roadside restaurant. The team entered but were stopped in their tracks. Fields recollected that,

The lady [owner or server] said nicely, “I'm sorry we can serve you [referencing the white players] but we can't serve him," talking about me. So, we left and went somewhere else. That's the only time that there were any difficulties.' 60

Feinberg told his teammates that he didn't wish to eat there, and they left. 'I was embarrassed,' he remembered, 'that was very embarrassing for me.'

Rat recalled that that incident was the first time most of the French players encountered J im Crow. 'We were profoundly shocked at that,' he said. Not that there wasn't discrimination against non-Caucasians in France-there was. Feinberg noted that French attitudes toward blacks at the time were 'more hidden, a lot deeper than in the United States.' Feinberg recalled that when traveling through France with PUC, he roomed with Antoine, son of a Caucasian French mother and black African father. T can't ever remember being refused a hotel,' he said.

59. Henry Fields, interview with the author, 30 June 2015.

60. All Fields quotes: Henry Fields, interview with the author, 30 June 2015. 
Fields helped explain the context of the era. At the time, he said, the government in Paris 'made the French people believe that you aren't racist, you don't have any problem against the coloureds, that only Americans are racist.' It was the Cold War, he noted. There were still old grievances that the old bipolar configuration exacerbated. I suffered from it,' he said, because the French thought that they were not racist.

This attitude, in part at least can be attributed to the French concept of citizenship. Under the republican model, anyone can become French if they speak the language, adopt the customs and styles of dress, and adhere to society's mores (though these 'standards' were set by the French establishment). There was some comfort that other 'outsider' groups, such as the Polish, Italian, and Portuguese immigrants who settled in France, also experienced discrimination for several generations until their offspring assimilated into society. Yet, black French and those from the Maghreb had to work harder than their white counterparts to prove their abilities, whether it was on the court, in school, or in life. 61

Despite the incident, Fields thought the trip was fantastic and helped prove that not all Americans were racist. They were expecting to see people saying “you can’t be together,'” he said of his French teammates. 'They were expecting blacks on one side of the street and whites on the other. That's what you read about. But, the only time they saw that there was a problem was in Georgia.' Fields noted, 'that was the only time that there was any difference,' in how he was treated. Based on what his young French teammates saw on television back home, 'they expected that to be happening all the time.'

61. Lindsay Sarah Krasnoff, ‘Can Football Save France in a Post-Charlie Hebdo World?’ CNN International Sport, 13 March 2015. 
The trip was thus a potent illustration of the power of sports exchanges as a means to learn more about a different society based on such people-to-people interactions. The young PUC players who travelled to the United States were not necessarily the typical representatives of their generation. They favoured basketball, a sport not part of the cultural mainstream, and had high regard for the United States. Many of the PUCists came away with favourable impressions of France's sister republic in most matters, save that of race relations. Decades later, they recalled these experiences and incorporated elements of the American game (training, tactics, gear) in their efforts to reverse the French basketball catastrophe.

\section{Basketball in the Sports Crisis}

By the time the team returned from its second U.S. romp, the sports situation in France had drastically changed. The 1960 Rome Olympics lifted the veil on the notion that France could lead through athletic prowess. That summer, French Olympians placed twenty-fifth in the medal table, with two silvers and three bronzes. The basketball team, expected to do well, was quickly eliminated from the tournament, piercing the belief that they were the best in the world. The Games were an embarrassment and demonstrated that sport was trickier to deploy as a soft power tool than foreseen by the French government.

At the instigation of de Gaulle, the government launched an inquiry and found several explanations for the poor showing: a youth that preferred other leisure time activities to practicing sports, a long school day that prohibited youth athletics in any serious way, sports facilities that were old, out of date, and/ or difficult to access. With regard to the nation's elite athletes, who held regular full-time jobs and trained on weekends or at night, a lack of sufficient time to prepare was cited. More importantly, 
government and press reports alike highlighted the larger issue: France lacked a national sports culture to foster athletic achievement. 62

The quickly coined 'sports crisis' took Les Tricolores hostage; the team did not qualify for another Olympic Games until 1984, and after 1963, France was absent from the World Championship until 1986. Combined with the lack of accolades in other major sports events, including football, the image of a France in flux was augmented and exacerbated by the événements of May 1968.

Change came in the 1970s after a series of four year sports plans in the 1960s failed to remedy the situation. The 1975 Mazeaud Law legislated for the first time a place for sport within the national culture, devoted funds to develop it, and established programs to detect and train the next generation of elite athletes. Basketball benefitted. The French Basketball Federation (FFBB) led efforts to reverse that sport's decline, informed by officials who observed the sport in the United States twenty years earlier, an important testimony to the importance of sports exchanges, even the unofficial, grass-roots level variety.

Attempts were made to improve the physical bodies that competed on the hardcourt. The FFBB's Dr. J acques Huguet-the PUC comic who entertained Chicago's Pump Room—pushed for better diet and nutrition for basketball players, especially those at the elite level, as more nutritious food could produce healthy players andeventually-taller players, a key tool to winning games in Cold War Europe. ${ }^{63} \mathrm{He}$ also introduced better physical conditioning so as to strengthen players and help protect 
them from injury. Huguet was inducted in the Academy of French Basketball in 2012 as a legend who helped change the sport.

Efforts were made to improve results through better coaching and opening the game up to international players. 'Gentleman' Henry Fields coached generations of youths after finishing a long career as a semi-professional player at Monaco and Antibes. Through his drills, young basketteurs practiced the impeccable defensive tactics of Bill Russell and produced new waves of technically proficient players. Fields was far from the only American player-coach to leave his mark in the hexagone; however, he was one of the earliest and most respected. ${ }^{64}$ He was inducted into the Academy of French Basketball in 2014 for his devotion to the game.

New structures were deployed to train the nation's most promising athletes from an early age. The Mazeaud Law created the Institute National de Sport, de l'Expertise et de la Performance (INSEP), the national sports institute, in Paris' Bois de Vincennes where elite athletes could train under specialised coaches, earn a subsidy, and not have to worry about a full-time job. 65 In 1984, the FFBB created the Centre Fédérale de Basket-Ball (CFBB) at INSEP. This entity formed and nurtured elite youth talent by congregating the nation's best players together to finish their athletic and academic training under the watchful eyes of sports experts. One such authority was Michel Rat, the PUC player aghast at the treatment accorded Fields in Georgia. Under Rat's tutelage, the first generation of French players to be drafted into the NBA directly from France was formed: Tony Parker, Boris Diaw, and Ronny Turiaf (who attended INSEP before

64 A 1968 rule change by the FFBB allowed each team to field two foreign players, a move then-FFBB President Busnel made to force the French game to assimilate new styles of play and thus improve. Despite the subsequent 'American colonization' of the 1960s and 1970s and the at times negative press discourse that covered it, Fields remained an icon.

65. INSEP was originally named the Institute National de Sport et d'Éducation Physique; over the years its name went through several transformations in recognition of the changing attitudes and foci vis-à-vis sport. 
playing at Gonzaga and being drafted). In 2014, Rat was inducted into the Academy of French Basketball for his life's work, and in 2015 he was named President of the CFBB.

All of these measures in which PUC alumni played crucial roles helped the fortunes of French basketball. For Rat, the influence of American players in France, especially Feinberg and Fields at PUC, helped to improve the game. They brought us the tactics,' Rat said.

\section{Conclusion}

PUC's barnstorming tours were influential. Through sport, these Frenchmen saw the United States, learned about its political, economic, and social system, met every day Americans, and returned with mostly favourable impressions of their host country, an important consideration given cyclical French anti-Americanism. The two trips would not have occurred without the foresight and drive of Martin Feinberg.

The basketballer from Cleveland had a front-row seat from which to evaluate the changes in the French sport. Today, I see a lot more technical training,' he said, 'a lot more defence, attack, and shooting particularly. So much more concentration on the basics.' Indeed, it is these very things, the basics and technicalities of the game, that French players are known for today, an odd reversal of fate from the era of PUC.

The informal nature of the trip ensured that the players viewed the United States uncoloured by any official information program. In showing his friends around the country, Feinberg relayed the many attributes-and some negatives-that made the United States. These early French-American basketball exchanges created lasting impressions on young players in ways traditional diplomacy and diplomats rarely could. Set against the larger context of post-war French anxieties and reconstruction, a FrenchAmerican Cold War diplomacy that was often fraught with tension over international 
influence, and race relations in both countries, these trips are noteworthy. Alumni of PUC's U.S. trips matured and entered the rungs of basketball coaching and officialdom. Importantly, the PUC cohort orchestrated France's late twentieth century basketball renaissance, one that was uniquely 'French' but heavily informed by their U.S. experience. The PUC's barnstorming tours of the United States had many short term dividends, as well as longer-term ones that still play out on the court-and at the podium. Today Les Bleus accumulate medals, international titles, and are a leading supplier of basketteurs to the world's elite league, the NBA, a twenty-first century version of the original PUC barnstormers. 